ISSN: 2521-0505 (online)

\title{
CAN POLITICAL CONNECTIONS OF INDEPENDENT DIRECTORS IMPROVE FIRM PERFORMANCE? EVIDENCE OF CHINESE LISTED MANUFACTURING COMPANIES OVER 2008 - 2013
}

\author{
Changzheng Zhang, Jiao Zhang, Qian Guo \\ Xi'an University of Technology, School of Economics \& Management, Xi'an China \\ *Corresponding Author Email: zcz7901@163.com
}

This is an open access article distributed under the Creative Commons Attribution License, which permits unrestricted use, distribution, and reproduction in any medium, provided the original work is properly cited.

\section{ARTICLE DETAILS}

\section{Article History}

Received 12 November 2017 Accepted 12 December 2017 Available online 1 January 2018

\section{ABSTRACT}

The paper investigates the effect of the political connections of independent directors on firm performance by choosing the panel data consisting of 2994 firm-year observations in Chinese listed manufacturing companies during 2008-2013 as the sample. Empirical analysis by adopting multiple regression analysis based on OLS with SPSS19.0 makes a new finding, i.e., in manufacturing companies in China, there is a positive relationship between the political connections of independent directors and firm performance measured by ROE and EPS. Further investigation shows that the richness of independent directors' political connections improves firm performance by providing more resources instead of inputting extra knowledge, ideas or perspectives. Therefore, the political connections of independent directors have potential negative effects on firm's long-termed competitive edge, since current richer resources would lower the recognition of the top executives on the importance of enhancing internal core competence.

\section{KEYWORDS}

Political connections, Independent directors, firm performance, listed companies

\section{INTRODUCTION}

According to a study, a growing body of literature has addressed the role of political connections in affecting firm running and political connections are an important issue that has been found to be highly influential in developing countries [1]. On the one hand, political connections are viewed as an important tool to make firms get success at a higher possibility; On the other hand, one of the researcher also state that politically connected firms are widely perceived to be closely related to poor corporate governance practices and are riskier as perceived by stakeholders such as auditors and lenders [2]. According to the existing literature, political connections are a double-edged sword. It can either enhance or jeopardize a firm's value.

To be specific, in existing literature, a negative effect of political connections on firm performance has been found. As an example, one of the researcher argue that when political control due to firm's political connections is curtailed, firm performance improves [3]. For another example, a study shows that firms with politically connected CEOs under-perform those without political connections by $37 \%$ [4]. In some other studies, political connections of executives can play a positive roles in helping firms to obtain more favorable bank loans providing firms with easier access to equity capital and debt financing, bringing lower tax rates to firms, striving for preferential regulatory treatments on firms and government bailouts and finally improving firm performance [5], [6], [7], [8]. On the whole, though the opposite view exists, it has been widely acknowledged by the existing literature that political connections add value to firms [7], [8], [10].

Evidently, though the effects of political connections on firm performance have received considerable research interest, the question of whether political connections enhance firm value has mixed findings [10]. A further systematic investigation on the existing studies on this issue shows that besides the differences in the choices of empirical samples, methods and measures, there are still other critical reasons which lead to the confused conclusions on the relationship between political connections and firm performance. According to our opinion, different owners of political connections would lead to various firm performance consequences, which has been ignored by the prior literature to a large degree. According to a study, most of the existing literature focuses the political connections belonging to CEOs, a small part of literature addresses the political connections belonging to the common executives and board members, while very limited literature sees the importance of the political connections of the independent directors [11], [12], [13].

In recent studies, independent directors in the board are particularly important in developing economies, which are characterized by relatively weaker governance mechanisms and poorer institutions such as financial markets, regulators, monitoring and legal systems [14]. However according to one of the researcher, the question of whether and how will the presence of independent directors affect firm performance is still theoretically debated and empirically inconclusive [15].The scholars of the existing studies have investigated the relationship of independent directors and firm performance mainly from the perspectives of independent directors' independence, proportion, background, characteristic and compensation [16]. On the whole, the findings of the existing Chinese literature are similar to those of the international literature. That is to say, the empirical evidence on the relationship between independent directors and firm performance is actually confused and mixed, either positive or negative or zero correlation. Facing such confusing conclusions, we accept the explanation of one of the scholars on this issue, who argue that different types of independent directors with distinct role identities have different orientations towards decision making, which are reflected in firm's longterm and short term firm performance [17]. According to this view, independent directors of rich political connections would have distinct role identities relative to the other independent directors, and thus they would potentially have different performance consequences. However, existing literature, except for very limited studies, has completely ignored the differences between politically connected independent directors and other types of independent directors.

In order to fill this gap, this study advances the extant literature by investigating the effect of political connections belonging to the independent directors on firm performance. The paper chooses the unbalanced panel data consisting of 2994 firm-years in Chinese listed manufacturing companies over 2008-2013 as the sample, adopts the multiple regression analysis method based on OLS as the empirical analysis method, and contributes a new finding on this topic: There is a positive relationship between political connections of the independent directors and firm performance in Chinese listed manufacturing companies. However, such a positive effect is based on resource enrichment derived from political connections instead of new knowledge 
or valuable perspectives brought by political connections.

The remainders of the paper are arranged as follows. Section 2 is the literature review and hypothesis. Section 3 provides the measures and sample. Section 4 shows the empirical results. Section 5 is the conclusions and suggestions on future research.

\section{LITERATURE AND HYPOTHESIS}

\subsection{Research on effect of independent directors on firm performance}

There is no any consensus as regards the impact of independent directors on firm performance because empirical evidence on the correlation between independent directors and firm performance is not consistent and even controversial. There exists either a positive or a negative correlation, or a non-linear correlation, or no correlation between independent directors and firm performance.

First, there is a positive correlation between the two concepts. For example, a researcher conduct a meta-analysis of 63 empirical studies on the correlation between board composition and firm performance and the result of their work indicates that the higher ratio of independent directors is associated with higher firm performance [18]. Lots of subsequent studies have confirmed to their result [19], [20], [21]. As most recent example, a researcher have analyze how the tenure and the number of directorships of independent directors can affect the relationship between board independence and firm performance by adopting a sample composed of US listed firms for the period 2008-2012 [22]. Both the empirical analysis and their robustness checks and sensitivity analysis have confirmed that the board's independence positively influences firm performance.

Second, a negative correlation exists between the two concepts. For example, there is an influential and valuable empirical study that have been conducted with the first large sample, long-horizon study of whether the proportion of independent directors affects firm performance [23]. They conclude that there is a strikingly significant negative correlation between the proportion of independent directors and firm performance measured by a large variety of accounting measures. The finding is also confirmed by a stream of other empirical literature [24], [25]. For another more recent study conducted by one of the researcher about the effect of legislation environment on the relation between independent director and firm performance in China with the purpose of providing the Chinese market evidence for the international corporate governance study is focused on [26]. By adopting the mixed cross-sectional data of listed companies in Shanghai and Shenzhen Stock Exchange from 1998 to 2005, they have concluded that the proportion of independent director is significantly and negatively related to firm performance. However, the legislation does not seem to enhance or weaken the negative relationship between independent director and firm performance.

Third, a context-dependent correlation exists between the two concepts. Facing the fact that family businesses are a group of heterogeneous companies with different levels of family involvement in the business, a researcher have tried to empirically explore how the combination of different family business governance structures jointly shape the effect of independent directors on family business performance in an understudied collectivist cultural setting [27]. By adopting Qualitative Comparative Analysis (QCA) on a sample of 74 Lebanese family companies, their study finds that, depending on the family companies' governance structure, the existence of independent directors on the board would result in either positive or negative firm performance. That is to say, the relationship between independent directors and firm performance is contingent on some contextual variables.

Fourth, there is a nonlinear relationship between independent directors and firm performance. As an example, a group of researchers have investigated the effect of independent directors on firm performance by adopting a sample of companies with a family ownership structure [28]. By controlling for the two potential problems of endogeneity and unobserved heterogeneity, their final results prove that there is an inverted U-shaped relationship between independent directors and firm performance, which allows us to identify the optimal level of independent directors on the board. Some other studies have also confirmed the result. In their study, the relationship between board independence and firm performance is examined in a few countries, and the results indicate a mixed nonlinear relation between the proportions of independent directors and firm performance [29]. Such results may mean that high levels of independent directors are not always in the best interests of minority shareholders. This school of literature indicates that there is an optimum level of independent directors to maximize firm performance, and the existence of independent directors on board should be monitored in order to bring positive shareholder values.

Finally, there is no association between independent directors and firm performance. Though many empirical studies have agreed on the importance of independent directors to the success of a firm, some other studies embrace an zero relationship between the two. For example, the earliest evidence confirming to this view is perhaps provided by a group of researchers who indicate that there is no significant and stable relationship between the proportion of independent directors and the firm's profitability in the same year in 1970s under the condition of controlling the possible endogeneity issue [30]. Several other following studies also find such a result [31], [32]. According to a study, the possible negative of independent directors on firm performance is that, though firms with high ratio of independent directors in a board face less frequent financial pressure and firms with many independent directors have lower probability of going towards bankruptcy when a business environment worsens such a fact would make the firms become lazy in improving their management efficiency and changing their incorrect strategies [33], [34]. The positive effect deriving form more resources due to independent directors would be offset by the negative effect deriving from becoming lazy due to more independent directors in management. In this case, the relationship between independent directors and firm performance has the possibility to be insignificant.

This study argues that the existence of different views on the effect of the independent directors on firm performance derives from the ignorance on the political connections of the independent directors. Since independent directors with different political backgrounds would have very different effects on firm running, the existing studies without paying any attention to such political connections of the independent directors would naturally make different conclusions when they face various independent director's components with different political connections.

\subsection{Research on consequences of executives' political connections}

Based on a study, the effect of executives' political connections has been the hottest issue during the past decade years [30]. According to a researcher no matter in developing or developed countries, it is popular to see that many entrepreneurs themselves have certain government backgrounds or that enterprises employ executives or directors who have certain government backgrounds, and such a fact is especially widespread in countries with higher degree of corruption [35]. The primary reason for such a fact is that governments hold the distribution power for public resources and political connections can help enterprises to gain more governmental resources [30]. Based on the literature review, executives' political connections can affect or even determine many important organizational variables to a good degree, which mainly include firm performance, non-market outcomes, CEO turnover, firm internalization, corporate cash holdings, bank loans and firm value.

First, lots of studies have found essential effect of executives' political connections on firm performance. For example, a study was conducted to empirically investigate the relationship between political connections and firm performance, by adopting a sample of Chinese private enterprises over the period from 2002 to 2006 [36]. Under the condition of controlling the potential endogenous problem, they find a negative relationship between the rate of the political connections of the private enterprises and firm performance. However, some other scholars hold the opposite view. For example, a study has been conducted to identify the role of being a Party member for the entrepreneurs during the operation of private enterprises in China based on a nation-wide survey of private firms [37]. Their finding is that, the CEOs' Party membership has a positive effect on the performance of their firms when human capital and other relevant variables are controlled, and such an effect would be more important to firm performance in regions of China with relatively weaker market institutions and poorer legal protection.

Second, there is certain effect of political connections on non-market outcomes. For example, drawing on the literature on the liability of foreignness and transaction cost economics, a study confirms that foreign multinational enterprises (MNEs) can acquire political capital with the purpose of achieving better non-market outcomes by hiring outside lobbyists with rich political resources than by using internal lobbyists [38]. This finding enriches our knowledge about how foreign MNEs acquire and use political capital, and about whether and how they achieve their non-market strategic goals.

Third, there is certain essential effect of executives' political connections on CEO turnover. For example, a scholar argues that political connections, however, may turn into political constraints when the CEOs 
fail to perform but entrench themselves by misusing such political connections [39]. By adopting CEO turnover data for Chinese firms, they show that politically connected CEOs have significantly, longer tenure, lower turnover, and lower turnover-performance sensitivity than nonpolitically connected CEOs, especially in firms that are politically vulnerable in their nature. The results suggest that there are certain severe entrenchments of executives' political connections in Chinese private firms which would cause pronounced inefficiency in private sector.

Fourth, executives' political connections can affect firm internalization to a good degree. For instance, a researcher has explored the effect of the board's political connections and their interaction with CEO's political connections on firm internationalization. Based on resource dependence perspective and social capital theory, his study proposes that the board's political connections will exert a positive effect on firm internationalization, and CEO's local government connections will such a relationship, while CEO's central government connections will strengthen such a relationship [40]. The empirical results based on 1010 Chinese firms during 2001 to 2005 do confirm the positive effect of the board's political connections and the moderating effect of CEO's political connections with the central government.

Fifth, executives' political connections can determine corporate cash holding policy to a certain degree. A study has been conducted to highlight the relationship between corporate liquidity and political connections measured via lobbying expenditures, which is an interesting question as amounts of the motives for holding cash should be diminished by executives' political ties [41]. Empirical results show that there is a significant and negative relationship between corporate cash holding levels and political connections. On the whole, such results suggest companies should react optimally to the reduced benefits of cash holdings linked to political ties. Furthermore, by adopting the panel data of 150 non-financial firms ranging from 2001 to 2014, a group of researchers have also confirmed such a negative relationship when they investigate the interplay of political capital (i.e., political connections) on the relationship of the board's characteristics and cash holding policy [42].

Sixth, executives' political connections can determine firm value to a good degree. For instance, using the network of college classmates among corporate directors and politicians from 1999 to 2010, a scholar has found the positive and significant effect of social-network based political connections on firm value [43]. And further, political capital is more valuable in a state with a higher level of regulation and corruption, in smaller firms, or in firms dependent on the support of external finance. Firms with rich political ties enjoy greater firm value. However, a researcher has identified some different findings on this issue [44]. In their study, it is found that political connections add little to the value of a company in Singapore where low political connections are due to better institutions and not confounded by favorable cultural factors. A further new finding is that in industries that are subject to more stringent government regulations, political connections appear to be somewhat important. And Political connections render the firms more susceptible to poorer governance practices.

Finally, executives' political connections can affect bank loans to an essential degree. A researcher has investigated whether the political ties of listed firms in the United States affect the cost and terms of loan contracts [45]. Using a hand-collected data set of the political connections of S\&P 500 companies over 2003-2008, they indicate that the cost of bank loans is significantly lower for companies that have board members with richer political connections. In a similar way, by adopting the method of event study on the presidential election in Taiwan during the whole year of 2000, a scholar has confirmed that political connections are positively correlated with preferential bank loans [46]. On the whole, the existing empirical results on the relationship between political ties and bank loans suggest that political connections can reduce the monitoring costs and credit risk faced by banks, which, in turn, would increase the possibility of getting greater bank loans and reduce the borrowers' cost of debt. Furthermore, by adopting a unique firm-level dataset for the manufacturing sector in Indonesia, a researcher also found that politically connected firms are more likely to be able to borrow from state-owned banks [12]. Moreover, being connected to the government raises the probability that a company can receive the full loan amount it has applied for. The improvement in access to finance from political connections is more prominent for small and medium enterprises than for large firms.

Based on a group of researchers, and besides the organizational variables mentioned above, executives' political connections can determine many other important organizational variables to a large degree, including trade expansion firm's dividend policy capital structure adjustment stock price crash risk corporate social responsibility positive abnormal returns to corporate stocks government bailouts during financial distress and preferential access to capital market [47], [48], [49], [50], [51], [10], [35], [53].

\subsection{Hypothesis on the relationship between independent directors'} political connections and firm performance

There are only very limited studies which focus the issue of the relationship between independent directors' political connections and firm performance, which mainly include a number of researchers [53], [49] First, using a sample of 1548 firms between 2006 and 2007, a researcher finds a positive link between the ratio of politically connected independent directors and firm performance [53]. Second, using 7487 firm-year observations from the Shanghai stock exchange during the period of 2003-2012, a researcher finds that the value effect and incentives of hiring independent directors with political ties are shaped by a firm's ownership structure [54]. However, there are at least two limitations of the two studies. One is that, manufacturing firms, which have obvious differences with the firms in other industries, have not received the specialized attention; The other is that, Tobins' $Q$, the measure of firm performance used in the two studies, is not suitable for Chinese listed companies, since the stock market's effectiveness of China has not reached to the standards of the Weak Form of Efficient Market. The traditional accounting indexes measuring financial performance are more suitable for Chinese listed firms, which will be adopted in this study.

According our opinion, manufacturing firms in countries where the government controls the allocation of resources have high incentives to seek political connections by hiring politicians or ex-politicians as their top executives, since political connections of independent directors would have substantial effects on firm performance based on the following reasons.

According to study, independent directors of rich political connections potentially can help their firms obtain more preferential regulatory treatments and lower taxes rate which are of even greater importance for manufacturing companies in China [55]. Strict regulatory treatments and high taxes rate are two critical factors preventing the development of the Chinese manufacturing companies, while better political connections can induce the government authorities to use their discretionary power to set less strict regulatory treatments and much lower taxes rate. In fact, firms' top executives in China, especially the independent directors, with former government affiliations or experiences can invest in their established personal connections, networks or relationships with certain bureaucrats in order to get the preferential treatments for their firms from the governments both the local government and central government [56]. Evidently, Chinese manufacturing companies which continuously endure rather poor ROA and ROE would get significant increases in their profits.

Second, a researcher state that political connections can help private enterprises establish organizational legitimacy in China's transitional economy [57]. Hence, independent directors of rich political connections possibly have the capability to improve the organizational legitimacy of Chinese manufacturing listed companies. Organizational legitimacy can mitigate the possible unsuitable interventions in the normal operation of the manufacturing companies from multiple government departments, since many rules and policies regulating firm's running are very flexible in China's transitional economy. In China, the negative externalities associated with government intervention in the private enterprises are well known. According to a researcher, many public-sector institutions are imposing heavy burdens on private manufacturing companies due to their lackness of organizational legitimacy [58]. Existing literature shows that executives with good direct political access can cope with the grabbing hand of government more easily. Hence, higher legitimacy due to political connections of independent directors lowers the possibility of receiving too much extra monitoring or even disruptive behavior from the government, since the private firms with rich political connections would be viewed as one of them.

Third, independent directors of rich political connections can help firms get enough loans with rather lower interest from the state-owned banks. Manufacturing companies are typically capital-intensive, which need heavy funds for R\&D investment and equipment purchasing and facilitates establishment. However, due to the fact that the Chinese manufacturing companies mainly belong to the low-end manufacturing industry, they are very different to meet the risk and benefit evaluation of the banks. Political connections which are derived from an individual's membership of the Chinese People's Congress, membership of legislative bodies, managerial experience in state-owned firms, or membership of Communist Party, can help firms get access to greater loans. As an example, a researcher finds that access to bank loans is significantly easier for CEOs who belong to the Chinese People's Congress [59]. Likewise, a researcher indicates that entrepreneur's membership of legislative bodies would improve firm's access to bank loans, especially 
for SMEs, while another researcher find that CEOs who are party members or who have had previous managerial experience in state-owned firms are less likely to feel discriminated against by state-owned banks than their contemporaries that are not party members [60], [37]. What is more, the recent study has found a positive relationship between membership of the Communist Party and access to loans from state-owned banks. From the perspective of the bank, it has been proved that politically connected banks have better access to lending to politically connected firms [56], [9]. Therefore, it can be concluded that the political connections of independent directors can help firms to get enough loans. Fourth, a study shows that rich political connections would bring the firms with the newest information on industry policies, which are of great importance for manufacturing firms to capture the upcoming business opportunities [61]. Evidently, running in a "competitive red sea", manufacturing companies in China face much heavier competition than companies of any other industries do. To know the related industry policies at the first time or even before the issue of such policies is of significance to manufacturing companies. The reason is that, once they know the forthcoming policies before the other competitors, they can adjust or optimize their strategies or plans according to the requirements of the new policies, and thus they can prevent possible losses or acquire higher benefits due to the new policies. According to our view, political connections of independent directors can also be helpful for firms to get access to such newest information, and thus firm performance would be improved.

Fifth, a study also shows independent directors of rich political connections would provide a signal of rich state-owned background, which would have great attraction for high talents, who actually like and appreciate the stability and high-reward of such enterprises. In 2010, according to a new survey of 21,000 graduating college students across China made by the human resources company named "www.chinahr.com", more Chinese talents prefer to work for a State-owned company than for a private-owned or a foreign-owned enterprise [62]. It is the first time since the year of 2000 that Chinese companies beat the foreign and private enterprises. Foreign companies have received a historically low vote of 23 percent, while state-owned businesses have received a historically high vote of more than 34 percent in the poll. The fact continues to be true given the global economic downward. Advantages such as much higher social status, more stable employment, less job pressure and better employee benefits at state-owned companies have been proved to be more attractive to college students and other talents. Hence, political connections of independent directors can be helpful in attracting high talents, who can improve quality of firm running and firm financial performance.

Finally, independent directors of rich political connections would help firms explore a new market in the other provinces of China by facilitating the coordination among local governments of different regions. Lots of studies have investigated the relationship between political connections and corporate diversification. Most of them have confirmed a positive relationship between the two. For instance, a researcher has clarified that the diversification level of politically connected firms is significantly higher than that of non-politically connected firms [62]. Their further investigations show that such relationship is much stronger in non-stateowned enterprises and in areas where government intervention is significantly greater. It is a new contribution to the corporate diversification literature by viewing political connections as an important driver of corporate diversification in emerging markets, such as China. According to this logic, as a typical kind of corporate diversification, regional diversification, i.e., exploring a new market in other area, can also be improved by political connections of independent directors, especially in the areas where the issue of Local Protectionism by the local governments is popular.

On the whole, political connections of independent directors can provide firms with extra essential resources, including the people, the information, the market, the policy and the money, etc. For the listed manufacturing companies, which operate mainly depending on all kinds of resources, such political connections may have great significance on firm performance improvement. This paper assumes that politically connected independent directors have both the willingness and capability in utilizing their political ties to improve firm running. Therefore, the paper proposes the following hypothesis.

H1: Political connections of independent directors have positive effects on firm performance in Chinese manufacturing companies.

\section{METHOD}

\subsection{Measures}

Political connections of independent directors (PCID_N, PCID_R). PCID_N is the number of independent directors who ever worked or are working in any governmental departments or authorities. That is to say, if any independent director has the experience of ever working in any governmental departments, PCID_N adds 1. PCID_R is the ratio of PCID_N to the size of the board.

Firm performance. Return on equity (ROE) is taken as the main measure of firm performance for hypothesis test, while earnings per share (EPS) is chosen as the alternative measure of firm performance, which will be used in robustness test.

Control variables. Following the popular literature in investigating the antecedents of firm performance, six control variables are chosen. (1) Technology intensity (TI) is coded as 1 when the sub-industry to which the sample firm belongs within the manufacturing industry is viewed as technology-intensive industry, otherwise TI is coded as 0 . In this study, according to the popular classification rules of industries in existing literature, the firms belonging to Metallurgical Industry, Computer, Communications and Other Electronic Equipment Manufacturing Industry, Pharmaceutical Manufacturing Industry, Special Equipment Manufacturing Industry and Automobile Manufacturing Industry are viewed as the technology-intensive companies. (2) Region (RG) is coded as 1 when the sample firm locates in the eastern provinces or regions in China, otherwise RG is coded as 0. (3) Firm size (LNFS) is the logarithm of total assets of the sample firm; (4) CEO duality (CD) is coded as 1 when the two positions of CEO (i.e., General Manager) and Chairman of the board are taken by one person; otherwise, $\mathrm{CD}$ is 0 ; (5) CEO age (AGE) is the chronological age of CEO. (6) The first large shareholder's ratio (FLSR) is the ratio of the share of the first large shareholder to the total share of the firm.

\subsection{Sample and data}

Taking all the listed manufacturing companies which exist during 2008-2013 in Shanghai and Shenzhen stock exchange as the research framework, the paper selects the final research sample according to the following requirements: (1) The firms should go public before 2007; (2) The firms should not be ever punished publicly by the government authorities for any reasons; (3) The firms should not be marked with ST, PT, SST, or *ST, etc.; (4) The firms should disclose all the data that the paper needs according to the above-mentioned measure design; (5) The firms should run relatively normally and smoothly, i.e., the firms whose financial data contain the singular data, too high financial loss, or too high net profit should not be allowed. According to such rules, 499 manufacturing firms are chosen, and a panel sample consisting of 2994 firm-years are designed. The descriptive statistics analysis and correlation analysis results are shown in Table.1.

Table1: Descriptive statistics and correlation coefficients

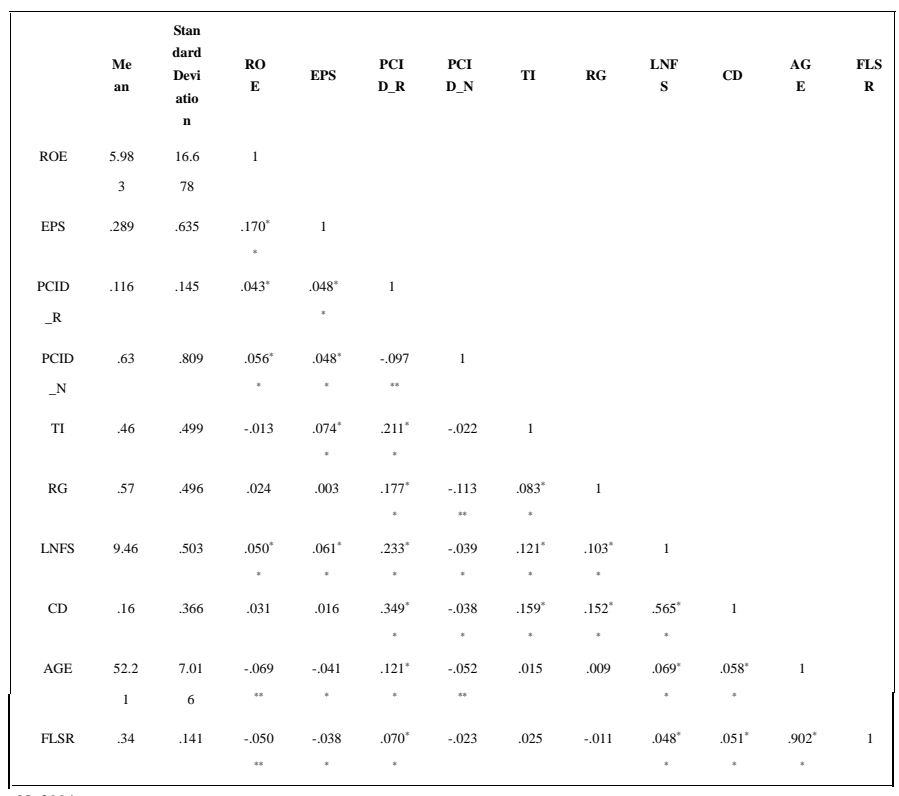

** represents significance level of 0.05

**** represents significance level of 0.01

\section{EMPIRICAL TEST}

\subsection{Main results}

In order to test H1, the paper designs Model 1 based on OLS which takes ROE as the dependent variable, PCID_R as the predictor, and TI, RG, LNFS, $\mathrm{CD}, \mathrm{AGE}$ and FLSR as the control variables. 


$$
\begin{aligned}
R O E_{i t}= & \alpha+\beta_{0} P C I D_{-} R_{i t}+\beta_{1} T I_{i t}+\beta_{2} R G_{i t}+\beta_{3} L N F S_{i t}+\beta_{4} C D_{i t}+\beta_{5} A G E_{i t} \\
& \beta_{6} F L S R_{i t}+\varepsilon_{i t}
\end{aligned}
$$

The paper makes the regression analysis on Mode 11 by adopting the panel data with 2994 firm-years. Results are shown in Table 2.

Table 2: Regression results of Model 1

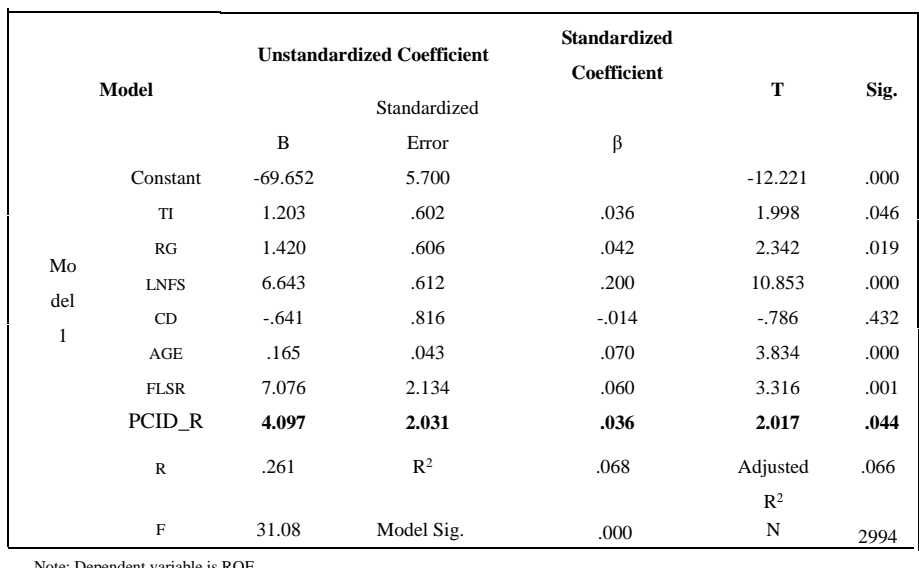

In Table 2, the standardized regression coefficient of PCID_R is 0.036 $(\mathrm{T}=-2.017, \mathrm{P}<0.05)$. That means $\mathrm{H} 1$ is confirmed. Our data supports that the ratio of independent directors has pronounced and positive effects on firm performance.

Table 3: Regression results of Model 2

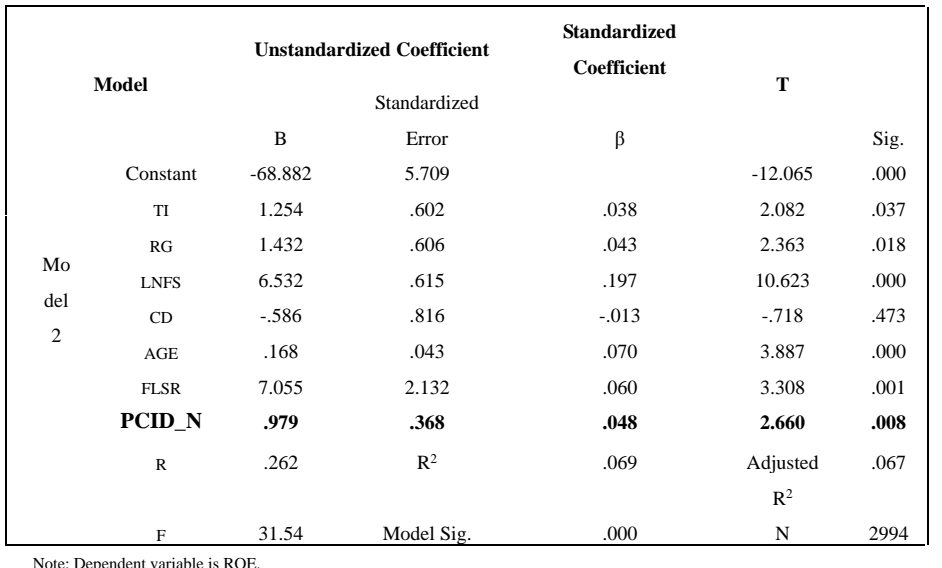

When the study changes PCID_R into PCID_N in Model 1, a new model investigating the number of politically connected independent directors on firm performance is built, which can be named as Model 2. The regression results of Model 2 by adopting the research sample are shown in Table 3 . Results indicate that more politically connected independent directors would lead to higher firm performance

$$
\begin{gathered}
R O E_{i t}=\alpha+\beta_{0} P C I D_{-} N_{i t}+\beta_{1} T I_{i t}+\beta_{2} R G_{i t}+\beta_{3} L N F S_{i t}+\beta_{4} C D_{i t}+\beta_{5} A G E_{i t} \\
{ }_{6} F L S R_{i t}+\varepsilon_{i t}
\end{gathered}
$$

\subsection{Robustness test}

First, in order to test the robustness of the empirical results, the paper uses EPS as the alternative measure of performance to replace ROE in Model 1, and takes the refined Model 1 (i.e., Model $1^{*}$ ) to match the data. Results show that, the coefficient of PCID_R is $0.029(\mathrm{~T}=1.684, \mathrm{P}<0.1)$. H1 still holds.

$$
\begin{aligned}
E P S_{i t}=\alpha & \beta_{0} P C I D_{-} R_{i t}+\beta_{1} T I_{i t}+\beta_{2} R G_{i t}+\beta_{3} L N F S_{i t}+\beta_{4} C D_{i t}+\beta_{5} A G E_{i t} \\
& \beta_{6} F L S R_{i t}+\varepsilon_{i t}
\end{aligned}
$$

Second, in order to test the robustness of the empirical results, the paper uses EPS as the alternative measure of performance to replace ROE in Model 2 , and takes the refined Model 2 (i.e., Model $2^{*}$ ) to match the data. Results show that, the coefficient of PCID_NP is $0.048(\mathrm{~T}=2.660, \mathrm{P}<0.01)$. H1 still holds.

$$
\begin{gathered}
E P S_{i t}=\alpha+\beta_{0} P C I D_{-} N_{i t}+\beta_{1} T I_{i t}+\beta_{2} R G_{i t}+\beta_{3} L N F S_{i t}+\beta_{4} C D_{i t}+\beta_{5} A G E_{i t} \\
{ }_{6}{ } L S R_{i t}+\varepsilon_{i t}
\end{gathered}
$$

Third, since the former empirical models have not considered the issue of endogeneity, the robustness test in this section tries to deal with such a limitation. It has been found that the positive impact of political connections on firm performance estimated in IV regressions gets even stronger when the paper controls for the endogeneity of political connections. Due to the limitation of paper length, the detailed robustness test results are omitted in this section.

\subsection{Further investigation and discussion}

The authors argue that the reason why political connections of the independent directors are of positive effect on firm performance, which has been proved by the above-mentioned data analysis, mainly rely on that political connections can enrich the resources of firm running, instead of bringing new knowledge and perspectives. In order to test our argumentation, the study further explores the effect of PCID_R on performance volatility by changing ROE into ROEV, i.e., the standard error of the ROE over 2008-2013, in Model 1. Then Model 3 is constructed. The paper takes Model 3 to match the data. Regression results show that the coefficient of PCID_R on ROEV is $-0.004(\mathrm{~T}=-0.215, \mathrm{P}>0.1)$. Such a fact indicates that the political connections of independent directors have nothing to do with the stability of firm performance, which can be understood as the followings: Independent directors of rich political connections have no capability in improving firm running by providing the TMTs with extra new knowledge or perspectives.

$$
\begin{aligned}
R O E V_{i t}= & \alpha+\beta_{0} P C I D_{-} R_{i t}+\beta_{1} T I_{i t}+\beta_{2} R G_{i t}+\beta_{3} L N F S_{i t}+\beta_{4} C D_{i t}+\beta_{5} A G E_{i t} \\
& \beta_{6} F L S R_{i t}+\varepsilon_{i t}
\end{aligned}
$$

Further, the paper tries to compare the effects of political connections of the independent directors on firm performance between local government connections and central government connections. According to our expectations, the capability in providing resources and other political benefits of local government connections is smaller than that of central government connections. PCID_B refers to the number of the politically connected independent directors who work in Beijing. PCID_B can measure the richness of central government connections of independent directors. To replace PCID_R in Model 1 with PCID_B, Model 4 is constructed. The paper takes Model 4 to match the data.

\begin{tabular}{|c|c|c|c|c|c|c|}
\hline & \multirow[t]{2}{*}{ Model } & Unstanc & $\begin{array}{l}\text { ed Coefficient } \\
\text { Standardized }\end{array}$ & $\begin{array}{c}\text { Standardized } \\
\text { Coefficient }\end{array}$ & \multirow[t]{2}{*}{$\mathbf{T}$} & \multirow[t]{2}{*}{ Sig. } \\
\hline & & B & Error & $\beta$ & & \\
\hline & Constant & -70.064 & 5.686 & & -12.322 & .000 \\
\hline & TI & 1.130 & .600 & .034 & 1.883 & .060 \\
\hline & RG & 1.542 & .606 & .046 & 2.544 & .011 \\
\hline & LNFS & 6.559 & .611 & .198 & 10.736 & .000 \\
\hline Mo & $\mathrm{CD}$ & -.451 & .816 & -.010 & -.552 & .581 \\
\hline del & AGE & .168 & .043 & .071 & 3.984 & .000 \\
\hline \multirow[t]{4}{*}{4} & FLSR & 6.871 & 2.129 & .058 & 3.227 & .001 \\
\hline & PCID_B & 1.162 & .292 & .071 & 3.984 & .000 \\
\hline & $\mathrm{R}$ & .266 & $\mathrm{R}^{2}$ & .072 & $\begin{array}{c}\text { Adjusted } \\
\mathrm{R}^{2}\end{array}$ & .069 \\
\hline & $\mathrm{F}$ & 32.887 & Model Sig. & .000 & $\mathrm{~N}$ & 2994 \\
\hline
\end{tabular}

$$
\begin{gathered}
R O E_{i t}+\alpha=\underset{{ }_{6}}{\beta} P L C I R_{i t} \quad{ }_{i t} \quad B_{i t}+\beta T I_{i t}+\beta R G_{i t}+\beta L N F S_{i t}+\beta C D_{i t}+\beta A G E_{i t} \\
\quad \varepsilon \beta+
\end{gathered}
$$

Regression results in Table 4 show that the coefficient of PCID_B on ROE is 0.071 ( $\mathrm{T}=3.984, \mathrm{P}=0.000)$. Evidently, central government connections have higher performance consequences. It is confirmed again that the positive consequences of the independent directors' political connections on firm performance mainly come from the resource effects instead of the knowledge effects.

Table 4: Regression results of Model 4

Besides, the authors further explore the role of independent directors who have close links with other enterprises in determining firm performance. PCID_E refers to the number of other-firm-connected independent directors, who hold positions in other enterprises, no matter directors or executives. On the one hand, higher PCID_E may mean more experiences or resources from other enterprises (i.e., Resource hypothesis); on the other hand, higher PCID_E may lead to lower engagement of the other-firm-connected independent directors in playing their roles (i.e., Diligence hypothesis). To replace PCID_R in Model 1 with PCID_E, Model 5 is constructed. The paper takes Model 5 to match the data. 
Besides, the authors further explore the role of independent directors who have close links with other enterprises in determining firm performance. PCID_E refers to the number of other-firm-connected independent directors, who hold positions in other enterprises, no matter directors or executives. On the one hand, higher PCID_E may mean more experiences or resources from other enterprises (i.e., Resource hypothesis); on the other hand, higher PCID_E may lead to lower engagement of the other-firm-connected independent directors in playing their roles (i.e., Diligence hypothesis). To replace PCID_R in Model 1 with PCID_E, Model 5 is constructed. The paper takes Model 5 to match the data.

$$
\begin{aligned}
R O E_{i t}= & \alpha+\beta_{0} P C I D_{-} E_{i t}+\beta_{1} T I_{i t}+\beta_{2} R G_{i t}+\beta_{3} L N F S_{i t}+\beta_{4} C D_{i t}+\beta_{5} A G E_{i t} \\
& \beta_{6} F L S R_{i t}+\varepsilon_{i t}
\end{aligned}
$$

Regression results in Table 5 show that the standardized coefficient of PCID_E on ROE is -0.056 ( $\mathrm{T}=3.254, \mathrm{P}=0.002$ ). Compared with the effect of PCID_N or PCID_R, PCID_E has the opposite effect on firm performance. The fact indicates that independent directors holding positions in other enterprises would not bring benefits to the firms where they play the role of independent directors. Diligence hypothesis on other-firm-connected independent director is supported. That is to say, independent directors holding more positions in other companies would bring negative effects on firm performance due to their limited energy engagement as a good independent director.

Table 5: Regression results of Model 5

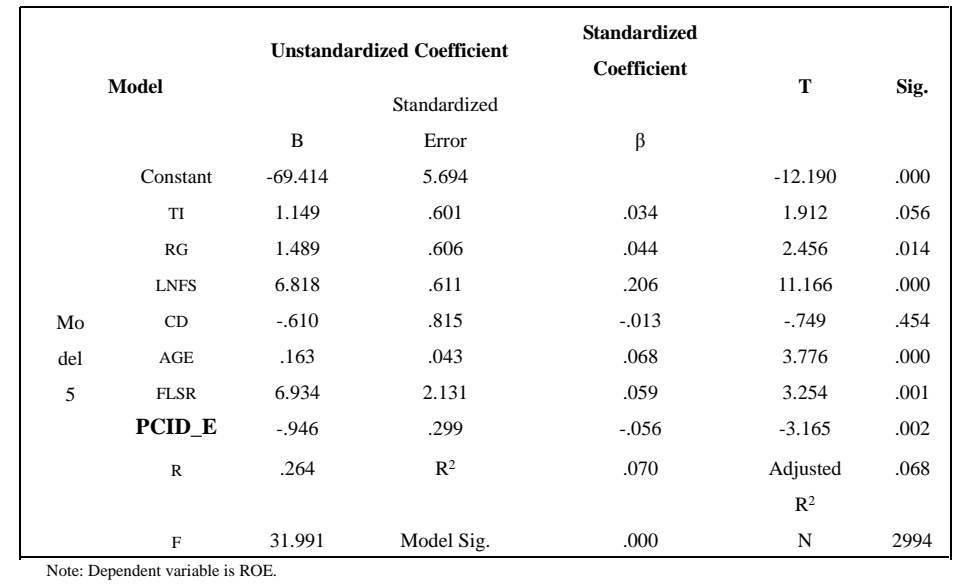

The reasons why the positive effect of independent directors' political connections on firm performance is rather weak may rely on the following points, which would address the dark side of the independent directors' political connections.

First, independent directors' political connections use related party transactions as a tunneling mechanism in developing countries, such as China, which would result in the decrease of firm performance. For example, by using data from Indonesia, a researcher has documented that politically connected firms use related party loans to tunnel resources, and that this effect is more pronounced for firms with government connections [63]. And they further document that politically connected firms manage earnings to conceal their tunneling activities. Hence, the positive effect of independent directors' political connections would be mitigated by the possible tunneling effect of their political connections.

Second, many studies have demonstrated that politically connected firms have lower default risk and credit risk, and they are more likely to be bailed out when in distress [8]. Less risky environment exerts weak pressure for the firms with rich political connections to improve their operation management efficiency and strategy management effectiveness, since they need not to strive for survival. What is more, a researcher also states that independent directors with rich political connections would spend more on entertainment and travel costs which will increase the operation cost of the firms [9]. Hence, the positive effect of independent directors' political connections would be mitigated by the possible efficiency decrease and cost increase due to their political connections.

Third, existing literature has expressed implicitly that rich political connections of independent directors would lead to overinvestment and riskier merger and acquisition (M\&A) decisions, both of which would predict the potential adverse effect of political connections on performance. On the one hand, by adopting a sample of 103 listed real estate firms from 1998 to 2012, a researcher find that politically connected firms are more likely to overinvest, and such behavior has resulted in a negative relationship between political connections and return on assets [64]. On the other hand, another researcher is using 29 recent high level anti-corruption cases in China to make a natural experiment, find that richer political connections would lead to more risky M\&A decisions, which would usually provide acquired enterprises with a higher takeover premium and consequently get worse post-M\&A performance [65].

Taken together, theoretical analysis and empirical data suggest that, though cultivating political connections could be a helpful choice in improving firm performance of the Chinese manufacturing companies, it is a rather risky investment and may not always bring remarkable benefits.

\subsection{Discussion on the control variables}

First, technology intensity is positively related with firm performance with good validity. In Table 2, the standardized regression coefficient of TI on ROE is $0.036(\mathrm{P}=0.046<0.05)$; In Table 3, the standardized regression coefficient of TI on ROE is $0.038 \quad(\mathrm{P}=0.037<0.05)$; In Table 4 , the standardized regression coefficient of TI on ROE is $0.034(\mathrm{P}=0.037<0.05)$; In Table 5 , the standardized regression coefficient of TI on ROE is 0.034 $(\mathrm{P}=0.056<0.1)$. In existing literature, technology-intensive companies would face higher risk and get higher potential performance. This empirical analysis result confirms the prior literature on the role of technology intensity in determining firm performance. However, the positive performance consequences of technology intensity are rather weak. Such a fact shows that CEOs of the technology-intensive manufacturing companies in China have no enough capability in facing the high risk and strict competition properly.

Second, manufacturing companies located in the eastern areas of China have higher performance than the ones located in the western and middle areas of China. In Table 2, the standardized regression coefficient of RG on ROE is $0.042(\mathrm{P}=0.019<0.05)$; In Table 3, the standardized regression coefficient of RG on ROE is $0.043(\mathrm{P}=0.018<0.05)$; In Table 4 , the standardized regression coefficient of RG on ROE is $0.046(\mathrm{P}=0.011<0.05)$; In Table 5, the standardized regression coefficient of RG on ROE is $0.044(\mathrm{P}=0.014<0.05)$. In existing literature, companies in eastern regions would have higher performance than their peers because of the differences in talents, institutional environment and management level between eastern areas and other areas. This empirical analysis result confirms that the regional gap in firm performance still exists, however, the regional gap has been reduced to a great degree with the implementation of the policy of Opening Up the West in China.

Third, firm size of manufacturing companies is positively related to firm performance in China. In Table 2, the standardized regression coefficient of LNFS on ROE is $0.200(\mathrm{P}=0.000)$; In Table 3, the standardized regression coefficient of LNFS on ROE is $0.197(\mathrm{P}=0.000)$; In Table 4, the standardized regression coefficient of LNFS on ROE is $0.198(\mathrm{P}=0.000)$; In Table 5, the standardized regression coefficient of LNFS on ROE is $0.206(\mathrm{P}=0.000)$. It can be seen that larger firms would get much higher performance than smaller firms. Based on a study, the result confirms to the prior literature on the relationship between firm size and firm performance [62]. Among the mentioned control variables in this paper, firm size has the most significant and strong effect on firm performance. Such a fact shows that Scale Economies Effect, instead of Innovation Effect or Differential Effect, is still the most important drive for improving firm performance in Chinese manufacturing companies.

Fourth, CEO age has positive effect on firm performance, which is rather significant than we have expected. In Table 2, the standardized regression coefficient of AGE on ROE is $0.070(\mathrm{P}=0.000)$; In Table 3, the standardized regression coefficient of AGE on ROE is $0.070(\mathrm{P}=0.000)$; In Table 4, the standardized regression coefficient of AGE on ROE is 0.071 ( $\mathrm{P}=0.000)$; In Table 5, the standardized regression coefficient of AGE on ROE is 0.068 $(\mathrm{P}=0.000)$. CEO age potentially has both negative and positive effects on firm performance. On the one hand, a researcher also state that the older CEOs would have richer experience, more available resources and higher interpersonal skills which would be helpful for improving firm performance [63]. On the other hand, older CEOs would possibly get somewhat conservative, react passively to the rapid change of the external environment and hold the obsolete management skills, which would be harmful for improving firm performance [66]. Our empirical results show that, in Chinese listed manufacturing companies, the positive effect of CEO age on firm performance exceeds the negative one. It is a new finding worthy of further in-depth investigation.

Finally, the shareholding ratio of the first large shareholder is positively related to firm performance. In Table 2, the standardized regression coefficient of FLSR on ROE is $0.060(\mathrm{P}=0.001)$; In Table 3, the standardized regression coefficient of FLSR on ROE is $0.060(\mathrm{P}=0.001)$; In Table 4, the standardized regression coefficient of FLSR on ROE is 0.058 ( $\mathrm{P}=0.001)$; In Table 5 , the standardized regression coefficient of FLSR on ROE is 0.059 $(\mathrm{P}=0.001)$. Such a result confirms to the conclusions of the recent literature on the performance consequences of ownership concentration. As an 
example, a researcher has found that the positive impact of ownership concentration on firm value detected in OLS regressions becomes even stronger when they control for the endogeneity of ownership by focusing on all non-financial companies traded on the Warsaw Stock Exchange [67]. For Chinese listed manufacturing companies, keeping moderate ownership concentration has positive effects on firm performance.

\section{CONCLUSIONS}

This paper investigates the determination of firm performance from the perspective of the political connections of independent directors, which has not been explored in detail till today by the Chinese scholars. Data from the Chinese listed manufacturing companies over 2008-2013 do prove that independent directors can improve firm performance by obtaining more resources for firm running with the application of their rich political connections to a good degree. However, such an improvement effect on firm performance does not come from the new ideas, new knowledge and better perspectives which would improve firms' long-termed competitive edge. Therefore, it is not a good choice for the listed manufacturing companies to improve their management level and competitive edge by paying more attention to enriching independent directors' political connections. Empirical results of this paper have provided a mechanism of political rent seeking from the perspective of independent directors, consistent with the institutional environment of China's economic management and political system.

Though the authors have provided rather robust and comprehensive evidence of the relationship between independent directors' political connections and firm performance in China's listed manufacturing companies, there are still many other important research questions that remain unexplored. To be specific, in the future, more empirical studies should be done in the following aspects: (1) Samples should go beyond the limitation of manufacturing companies; (2) Though the paper has examined some of the potential channels through which independent directors' political connections can affect firm performance, there are invariably other channels that should be explored; (3) Future research can also measure independent directors' political connections by adopting more reasonable indexes, such as the independent directors' administrative levels in government authorities, whether an independent director ever worked for a state-owned enterprise or not, or the number of independent directors who are Chinese Party members, etc. (4) Methods should adopt more stringent empirical models which considers the possible endogenous problems and more control variables; (5) Suggestions in policies on supervising political connections should be addressed in a greater manner.

\section{ACKNOWLEDGEMENTS}

This research was supported by Projects of the National Social Science Foundation of China under the Grant "15BGL109".

\section{REFERENCES}

[1] Poon W., Yap A.K., Lee T. 2013. The outcome of politically connected boards on commercial bank performance in Malaysia. Modern Applied Science, 7(1), pp.35-50.

[2] Bliss M.A., Gul F.A. 2012. Political connection and cost of debt: Some Malaysian evidence. Journal of Banking \& Finance, 36(5), pp.1520-1527.

[3] Lixin, X., Zhu, T., Lin, Y.M. 2002. Politician Control, Agency Problems and Ownership Reform: Evidence from China. Working paper. World Bank, Washington, DC.

[4] Joseph, F., Wong T.J., Zhang, T.Y. 2007. Politically Connected CEOs, Corporate Governance, and Post-IPO Performance of China's Newly Partially Privatized Firms. Journal of Financial Economics, 84(2), pp.330-57.

[5] Firth, M., Lin, C., Liu, P., Wong, S. 2009. Inside the black box: Bank credit allocation in China's private sector. Journal of Banking and Finance, 33, pp. 1144-1155.

[6] Boubakri, N., Cosset, J., Saffar, W. 2012 The impact of political connections on firm's operating performance and financing decisions. Journal of Financial Research, 35 (3), pp.397-423.

[7] Faccio, M. 2006. Politically connected firms. American Economic Review, 96, pp. 369-386.

[8] Faccio, M. 2010. Differences between politically connected and nonconnected firms: A cross country analysis. Financial Management, 39, pp. 905-928.
[9] Chi-Hsiou D.H, Jiang, Y.X., Liu, F.H., Tu, H., Wang, S. 2017. Bank political connections and performance in China. Journal of Financial Stability, October 32, pp.57-69.

[10] Goldman., Eitan., Rocholl, J., So, J.I. 2009. Do Politically Connected Boards Affect Firm Value?. Review of Financial Studies, 22(6), pp.2331-60.

[11] Habib, A., Muhammadi, A,H., Jiang, H. 2017. Political connections, related party transactions, and auditor choice: Evidence from Indonesia.Journal of Contemporary Accounting \& Economics, April, 13(1), pp.1-19.

[12] Fu, J.T., Shimamoto, D., Todo, Y. 2017. Can firms with political connections borrow more than those without? Evidence from firm-level data for Indonesia.Journal of Asian Economics, October, 52, pp.45-55.

[13] Hou, Q.S.May Hu Yuan Yuan.2017. Corporate innovation and political connections in Chinese listed firms. Pacific-Basin Finance Journal, December, 46, pp.158-176.

[14] Ujunwa A., Salami P. O. Umar A. H. 2013. CEO duality and firm performance: An integration of institutional perceptive with agency theory. International Journal of Social, Management, Economics and Business Engineering, 7(1), 97-103.

[15] Samara G. Berbegal-Mirabent J. 2017. Independent directors and family firm performance: does one size fit all? International Entrepreneurship \& Management Journal, 10 June, pp.1-24. DOI 10.1007/ s11365-017-0455-6

[16] Wenge Wang. 2014. Independent Directors and Corporate Performance In China: A Meta-Empirical Study. 2nd Economics \& Finance Conference, Vienna, pp. 577-608. Available at: http://proceedings.iises.net/ index.php?action=proceedingsIndexConference\&id $=4 \&$ page $=1$.

[17] Feng Y., Sidhu J. S. and Bosch F. A. J. V. D. 2014. Independent directors' professional role identities, board effectiveness, and firm performance. Academy of Management Annual Meeting Proceedings, (1), pp.13784-13784.

[18] Wagner III J. A., Stimpert J. L. Fubara E.I. 1998. Board Composition and Organizational Performance: Two Studies of Insider/Outsider Effects. Journal of Management Studies, 35 (5), pp.656-677.

[19] Ferris S. P., Jagannathan M. and Pritchard A. C. 2003. Too Busy to Mind the Business? Monitoring by Directors with Multiple Board Appointments. The Journal of Finance, 3, pp.1087-1111.

[20] Hillman A. J. 2005. Politicians on the board of directors: Do connections affect the bottom line? Journal of Management, 31, pp.464-481.

[21] Masulis R. W., Ruzzier C., Xiao S. Zhao S. 2012. Do Independent Directors Matter? [Online] Available at: http://ssrn.com/abstract=2022831 [Accessed 15 December 2013], pp.1-44.

[22] Nuria Reguera-Alvarado Francisco Bravo. 2017 The effect of independent directors' characteristics on firm performance: Tenure and multiple directorships. Research in International Business and Finance, 41, pp.590-599.

[23] Bhagat, S. and Black, B.S. 1996. Do Independent Directors Matter? [Online] Available at: http://www.law.columbia.edu/null/ Working+Paper + No? exclusive $=$ filemgr.download\&file_id $=64139$ \&showthumb $=0$ [Accessed 10 November 2013], pp.1-73.

[24] Boone, A.L., Field, L.C., Karpoff, J.M. and Raheja, C.G. 2007. The Determinants of Corporate Board Size and Composition: An Empirical Analysis. Journal of Financial Economics, 85, 66-101.

[25] Bhagat, S. and Bolton, B. 2008. Corporate Governance and Firm Performance. Journal of Corporate Finance, 14, 257-258.

[26] Wang S. Zhou Q. 2013. An Empirical Study on the Effect of Independent Directors on Firm Performance from the View of Regulation Environment. In: Qi E., Shen J., Dou R. (eds) The 19th International Conference on Industrial Engineering and Engineering Management. Springer, Berlin, Heidelberg.

[27] Georges Samara and Jasmina Berbegal-Mirabent. 2017. Independent directors and family firm performance: does one size fit all?. International 
Entrepreneurship and Management Journal, June 10, pp.1-24. https:// doi.org/10.1007/s11365-017-0455-6.

[28] Rebeca García-Ramos Myriam García-Olalla. (201. Independent directors, family ownership structure and firm financial performance. International Research Journal of Finance and Economics, May, 90, pp.6-24.

[29] SyedFuzi, S.F., AbdulHalim, S.A., Julizaerma, M.K. 2016. Board Independence and Firm Performance. Procedia Economics and Finance, 37, pp.460-465.

[30] Baysinger B.D. Butler H.N. 1985. Corporate Governance and the Board of Directors:Performance Effects of Changes in Board Composition. Journal of Law, Economics and Organization, 1 (1), pp.101-124.

[31] Faccio, M. 2006. Politically connected firms. American Economic Review, 96 (1), pp.369-386.

[32] Duchin, R., Matsusaka, J. G. Ozbas, O. 2010. When Are Outside Directors Effective?. Journal of Financial Economics, 96, pp.195-214.

[33] Elloumi, F. Gueyié, J. P. 2001. Financial distress and corporate governance: an empirical analysis. Corporate Governance, 1(1), pp.15-23.

[34] Daily, C.M., Dalton, D. R., Cannella A. A. 2003. Corporate Governance: Decades of Dialogue and Data. The Academy of Management Review, 28(3), pp.371-382.

[35] Faccio, M., Masulis, R., McConnell, J. 2006. Political connections and corporate bailouts. Journal of Finance, 61, pp. 2597-2635.

[36] Jian-ping, D., Yong, Z. 2009. Can Political Connection Improve the Performance of Private Enterprises. China Industrial Economics, 2, pp.98-108.

[37] Li, H.B., Meng, L.S., Wang, Q., Zhou, L.A. 2008. Political connections, financing and firm performance: Evidence from Chinese private firms. Journal of Development Economics, 87, pp.283-299.

[38] Kim, J.H. 2017. Government Contracts and Firm Boundary in Political Activities. ACAD MANAGE PROC, (Meeting Abstract Supplement) 13880. doi: 10.5465/AMBPP.2017.13880abstract.

[39] Cao, J., Lemmon M., Pan, X., Qian, M., Tian, G. G. 2012. Political capital vs. constraint: evidence of CEO entrenchment in Chinese private firms. Asian Finance Association (AsianFA) International Conference (pp. 1-40). Taipei, Taiwan: Asian Finance Association.

[40] Lebedev, S. 2017. Board Political Ties, CEO Political Ties, and Firm Internationalization. ACAD MANAGE PROC, 2017 (Meeting Abstract Supplement) 15258. doi: 10.5465/AMBPP.2017.15258abstract.

[41] Matthew, D.H., Kathleen P.F., Kelly, G., Jim O.W. 2014. Corporate Cash Holdings and Political Connections. Review of Quantitative Finance and Accounting, 42(1), pp.123-142.

[42] Kamal, S.U.Y. 2017. Board Characteristics, Political Connections, and Corporate Cash Holdings: The Role of Firm Size and Political Regime. Business \& Economic Review, 9(1), pp.157-180.

[43] Do, Q.A., Lee, Y.T., Nguyen, B.D. 2013. Political Connections and Firm Value: Evidence from the Regression Discontinuity Design of Close Gubernatorial Elections. LIEPP Working Paper, March, No15. (53p). Available at: http://www.sciencespo.fr/liepp/sites/sciencespo.fr.liepp/ files/WP15.pdf.

[44] James S. A., David K. D., Tiong Y. T. 2013. Political Connection and Firm Value. Asian Development Review, 30(2), pp.131-166.

[45] Zhang, M., Liu, Y.S., Xie, L., Ye, T.T. 2017. Does the cutoff of "red capital" raise a red flag? Political connections and stock price crash risk. The North American Journal of Economics and Finance, 39, pp.89-109.

[46] Yin, H.Y., Pei, G.S., Shean, B.C. 2013. Political connections, corporate governance and preferential bank loans. Pacific-Basin Finance Journal, 21(1), pp.1079-1101.

[47] Y, Lu. (2008). Political Connections and Trade Expansion: Evidence from Chinese Private Firms. Economics of Transition, 19 (2), pp.231-254.
[48] Zhong, Q, Fung, H.G., Huang, D.S., Shen, C.H. 2014. Cash dividends, expropriation, and political connections: Evidence from China. International Review of Economics \& Finance, 29, pp.260-272.

[49] Liu, X., Jiang, S.Q., Qiang, F.U. 2015. Institutional Environment,Political Connections and - -Evidence from Chinese Private Listed Firms. East China Economic Management, 37 (3), pp.162-165.

[50] Zhang, M., Su, J., Sun Na Shen, Y.F. 2015. Political Connections and Corporate Diversification: An Exploration of Chinese Firms. Emerging Markets Finance and Trade, 51(1), pp.1-13.

[51] Huang, H.F., Zhao, Z.R. 2016. The influence of political connection on corporate social responsibility_- evidence from Listed private companies in China. International Journal of Corporate Social Responsibility, 1: $9(19 \mathrm{ps})$.

[52] Carboni, M. 2017. Literature Review on Political Connections. In: The Financial Impact of Political Connections, pp.9-15. Palgrave Macmillan, Cham. DOI https://doi.org/10.1007/978-3-319.

[53] Luhang, Z. 2010. Political Connection of Independent Directors and Firm Performance. Contemporary Economy \& Management, 32(11), pp.20-25.

[54] Wang, L.H. 2015. Protection or expropriation: Politically connected independent directors in China. Journal of Banking \& Finance, 55, pp. $92-106$

[55] Li, H., Zhang, Y. 2007. The role of managers' political networking and functional experience in new venture performance: evidence from China's transition economy. Strategic Management Journal, 28(8), pp.791-804.

[56] Chen, Y., Touve, D. 2011. Conformity, political participation, and economic rewards: The case of Chinese private enterprises. Asia-Pacific Journal of Management, 28 (3), pp.529-553.

[57] Feng, T., Wang, G. 2010. How private enterprises establish organizational legitimacy in China's transitional economy. Journal of Management Development, 29(4), pp.377-393.

[58] Shleifer, A. R., Vishny, W. 2004. The Grabbing Hand: Government Pathologies and Their Cures. Harvard University Press.

[59] Bai, C. E., Lu,J., Tao, Z. 2006. Property rights protection and access to bank loans: Evidence from private enterprises in China. Economics of Transition, 14(4), pp.611-628.

[60] Zhou, W. 2009. Bank Financing in China's Private Sector: The Payoffs of Political Capital. World Development, 37(4), pp.787-799.

[61] Choi, E.K., Zhou K.X. 2001. Entrepreneurs and politics in the Chinese transitional economy: Political connections and rent-seeking. The China Review, 1, pp.111-135.

[62] China.com. Graduates prefer State-owned to foreign companies in China. 2010-03-20. Available at: http://english.china.com/zh_cn/ education/news/11020786/20100320/15862946.html.

[63] Habib, A., Muhammadi, A.H., Jiang, H.Y. 2017. Political Connections and Related Party Transactions: Evidence from Indonesia. The International Journal of Accounting, March, 52(1), pp. 45-63.

[64] Ling, L., Zhou, X.R., Liang, Q.Z,. Song, P.P., Zeng, H.J. 2016. Political connections, overinvestments and firm performance: Evidence from Chinese listed real estate firms. Finance Research Letters, August, 18,pp.328-333.

[65] Liu, Q.G., Luo, T.P., Tian, G. 2016. Political connections with corrupt government bureaucrats and corporate M\&A decisions: A natural experiment from the anti-corruption cases in China. Pacific-Basin Finance Journal, April, 37, pp.52-80.

[66] Serfling, M.A. 2014. CEO age and the riskiness of corporate policies. Journal of Corporate Finance, 25(2), pp.251-273.

[67] Grosfeld, I., National, C., La, D., Scientifique, R., École, D., Études, H. 2011. Ownership concentration and firm performance: evidence. Social Science Electronic Publishing, 87(2), 295-309. 